\title{
Fiscal Policy, Growth and Income Distribution in the UK
}

\author{
Keshab Bhattarai ${ }^{1}$, Jonathan Haughton ${ }^{2}$ and David G. Tuerck ${ }^{3}$ \\ ${ }^{1}$ University of Hull Business School, Hull, UK. \\ ${ }^{2}$ Suffolk University, Boston, MA 02108, USA. \\ ${ }^{3}$ Suffolk University and Beacon Hill Institute, Boston, MA 02108, USA \\ Correspondence: Keshab Bhattarai, University of Hull Business School, Hull, UK; email: K.R.Bhattarai@hull.ac.uk
}

Received: April 10, 2015

Accepted: April 23, 2015

Available online: May 19, 2015

doi:10.11114/aef.v2i3.830

URL: http://dx.doi.org/10.11114/aef.v2i3.830

\begin{abstract}
Income and income inequality increased substantially in the UK during the industrial revolution. Income inequality was the highest around 1880.This triggered enactments of more egalitarian tax and transfer system, which halved income inequality by the 1960s. Inequality has risen again with fiscal system reforms in the last five decades. By analysing solutions of a dynamic computable general equilibrium (DCGE) model we show how policies could be designed for the optimal equitable paths of UK economy in the 21 st century.
\end{abstract}

Keywords: growth, redistribution, fiscal policy in UK

JEL classifications: H2, H3, D3, E6, O41, O52

\section{Introduction}

The annual average growth rate of GDP per capita in the UK was 0.08 percent between AD 1 and 1830 and 1.5 percent between 1830 and 2008. ${ }^{1}$ The unprecedented economic growth brought about by the industrial revolution and the development of trade, commerce and capitalism not only made the UK a global economic leader from 1750 to 1850 , but also created wide gaps in the distribution of income and wealth between the rich and the poor. Analysing secular trends in income distribution, Kuznets (1955) found a widening of income inequality in England during the early phases of industrialization between 1780 and 1850, when the transition from the mercantilist state to the industrial society was most rapid. The process of urbanisation, lower death and higher birth rates, and rising rates of saving, investment, capital accumulation and profit contributed to this inequality, which remained high until 1875 . After the seminal work of Meade and Stone (1941) on national accounts and input-output systems, more information became available. This led to improvements in economic modelling and analyses of the tax system and its impact on household income (Meade et al. (1978)).

In an extensive study of the UK tax systems Mirrlees et al. (2010) recommend "a progressive, neutral tax system, that minimises economic distortions and is a right tool for achieving distributional objectives". They then conclude that "there are taxes that are fairer, less damaging, and simpler than those that we have now. To implement them will take a government ... willing to put long term strategy ahead of short term tactics". They warn that "the costs of not doing so are very large ... Economic welfare could be improved by many billions of pounds if the taxation of income, expenditure, profits, environmental externalities and saving were reformed."

In this paper we construct a dynamic CGE model (DCGE) to simulate how such reforms relate to the relative prices of goods and services and factors of production, to growth, and to the distribution of consumption and income in the UK economy.

The most recent analysis of the evolving patterns of income and consumption inequality in UK is in Blundell (2014), who models the process of income and consumption choices of households as a function of the variances or covariances of permanent and transitory shocks to the processes of income and consumption. He calibrates the dynamics of income and consumption inequality among the households to the PSID dataset from the US, and the BHPS (understanding society) dataset from the UK, to provide empirical validity to model predictions.

By incorporating inter-household income patterns, and substitution of labour across skill categories and of capital across sectors of production, the DCGE model proposed here aims to find the dynamically efficient path of the relative price 
system, and the optimal (and more equal) distribution of income that is feasible within the time and resource constraints of the economy as a whole. It aims to find out the optimal path of taxes, public spending and borrowing that would insure households against such income and consumption shocks and would allow them to maximise their life-time welfare in anticipation of shocks to preferences, technologies or public policies. The model assumes an efficient financial market for channelling savings to investments. The model's results show the path of the economy that would result from the recent reforms of 20, 40 and 45 percent direct tax rates for low, middle and high income households or from a 20 percent VAT or from a 20 percent corporate income tax rate or from the unification of the benefit system. It takes account of the more complicated economy-wide income and substitution effects across sectors and households over time.

Since the level of lifetime utility is the most relevant indicator of the welfare of households, we focus on the growth and inequality in it as caused by the changes in the relative prices that are distorted by fiscal policy measures including taxes, transfers and public spending. The level of welfare of every household can rise if the growth rate is higher, leading to more consumption of goods and services. Richer households often benefit more from it than the poor households, yet more equality of income, if associated with a lower growth rate, can reduce the level of the lifetime utility of every household as they have less for consumption and leisure.

It is also clear from the model that tax reforms designed to tackle short-run problems have detrimental effects on long-run growth, and may not be helpful in reducing the inequality in the distribution of income. Thus there is a clear trade-off between growth and equality. Greater equality in income alone does not automatically guarantee greater welfare for everyone, no matter what the configuration of the social welfare function may be. The levels of consumption and utility cannot grow persistently when the economy is not growing.

Redistribution occurs also through the provision of public goods. In the existing structure of public expenditure, the UK government spends about 65 percent of its budget on cash and in kind benefits. The remaining 35 percent of its expenditure is for pure public goods. Thus, it is important to consider both the revenue and spending components of the public budget, and income and expenditure sides of households simultaneously, while evaluating effects of fiscal policy on the price system and the allocation of resources on growth and redistribution of income. As taxes and transfers affect different categories of households and firms differently, a multi-household multi-sectoral DCGE model of the UK is an appropriate modelling framework for such analysis. Developing and applying such a model is the main contribution of this paper.

\subsection{Rise of public sector and income inequality in the UK}

Motivated by sentiments against rising inequality ${ }^{2}$ policy makers in the UK were able to promulgate a series of entitlement laws and include clauses for income redistribution in regular acts such as the Income Tax Act (1853) and the Finance Act (1909). In his "Poverty: A Study of Town Life", Joseph Rowntree (1902) had made several recommendations to fulfil the basic needs of poor people, such as social housing, and services including education and health, which required mobilisation of additional revenues from direct and indirect taxes. Adoption of an egalitarian tax-and-transfer system in this manner raised the size of the state in the economy to 12 percent of the national income by 1914; it was barely 3 percent in 1665 . Further expansion of the public sector relative to GDP occurred when the UK financed World Wars I and II by debt, which left a legacy of a large public sector in the UK. Acts aimed at relieving the war-devastated economy resulted in public commitment to the social security system as proposed in the Beveridge report of 1942, which raised the share of the public sector to around 40 percent of GDP. It has remained at around that level since then (see Table 1).

The share of the income going to top five percent fell from 46 percent in 1880 to 24 percent in 1947, while the share of the bottom 85 percent rose from 41 percent to 55 percent, as several entitlement laws relating to the tax and transfer system enacted by the UK parliament made the UK one of the most egalitarian countries in the world by 1960s. The large tax wedge between the pre- and post-tax income, contributed to a Gini coefficient of net income of just around 25 percent (see Table1).

By the 1970s, the tax-and-transfer system that began in the 1800s had eliminated poverty among households in the bottom income group. But income inequality rose again after a series of reforms of that system began in the 1980s (Jenkins (1966) and Atkinson and Voitchovsky (2011)). As shown in Table 1, the Gini coefficient of post-tax income, rose from 28.6 in the 1970s to 38.3 in the 2000s. Higher inflation, the principal burden of which falls on the low income households, has further reinforced this process. The average income of a household in the bottom decile is only 7 percent of the average income of an individual in the top decile, as can be seen from Figure 1. 


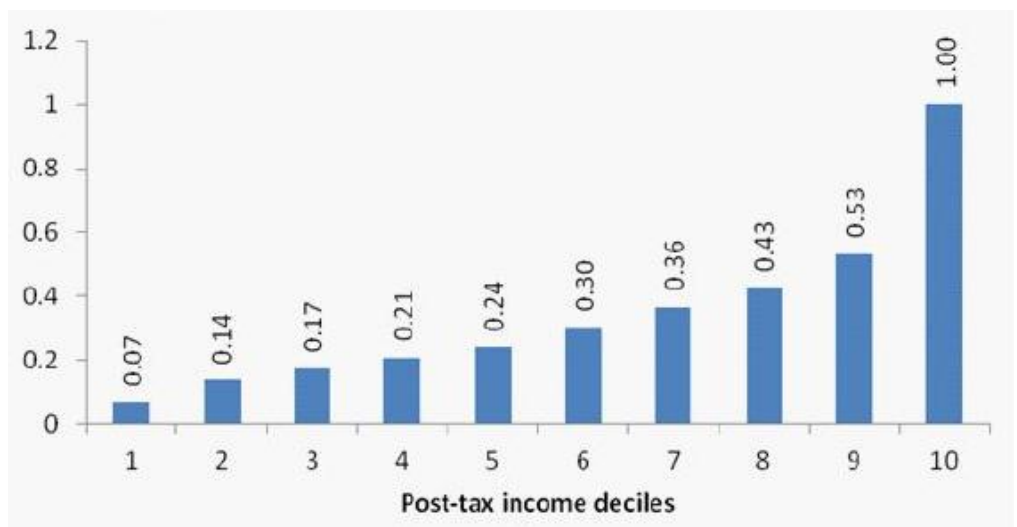

Figure 1. Post tax income distribution in the UK in 2010 (Data source: ONS).

Table 1. Fiscal policy, Growth and Inequality in the UK: Recent Trends

\begin{tabular}{lccccccc}
\hline & $1950 \mathrm{~s}$ & $1960 \mathrm{~s}$ & $1970 \mathrm{~s}$ & $1980 \mathrm{~s}$ & $1990 \mathrm{~s}$ & $2000 \mathrm{~s}$ & $2016^{*}$ \\
\hline Gov. revenue/GDP (\%) & 41.1 & 40.0 & 41.1 & 42.5 & 37.1 & 37.3 & $37.8^{*}$ \\
Gov. spending/GDP (\%) & 39.0 & 40.2 & 44.4 & 44.7 & 40.4 & 40.7 & $39.0^{*}$ \\
Budget surplus/GDP (\%) & 2.0 & -0.2 & -3.3 & -2.2 & -3.3 & -3.4 & $-5.5^{*}$ \\
Debt to GDP ratio (\%) & 145.0 & 89.6 & 49.9 & 40.6 & 34.6 & 34.2 & $85.0^{*}$ \\
Inflation, \% p.a. & 4.2 & 3.6 & 13.6 & 7.6 & 3.6 & 2.5 & $2.0^{*}$ \\
Growth rate, \% p.a. & 2.5 & 3.1 & 2.4 & 2.5 & 2.2 & 1.7 & $2.0^{*}$ \\
Gini of pre-tax income (/100) & 41.3 & 32.1 & 43.3 & 48.8 & 52.4 & 51.7 & $52^{*}$ \\
Gini of post-tax income (/100) & 35.4 & 25.1 & 28.6 & 33.8 & 38.6 & 38.3 & $39^{*}$ \\
\hline
\end{tabular}

Data source: ONS, IFS and http://www.ukpublicsp ending.co.uk/index.php; HM-Treasury. Gini for 1950 and 1960 rely on Stark (1972), Barna (1945), Nicholson (1964). * $=>$ an estimate.

Despite a rise in post-tax income inequality beginning in the 1980s (which took place in contradiction of the Kuznets hypothesis), the UK still underwent a significant amount of income redistribution under the existing tax-benefit system. Table 2 shows how, when we subtract direct and indirect taxes from cash and in-kind benefits, the net gains fall with household income. For instance in 2009, the net tax paid by an average household in the top 20 percent income group was around twenty thousand pounds - just enough to finance cash and in-kind benefits received by two average households in the bottom 40 percent, each of whom got a net amount of about ten thousand pounds, twice as much as their own contributions to the Treasury. The average size of benefits has risen also with the growth of the economy. The extent of redistribution is less in the middle income groups, where the net amount received by the third quintile almost matches the net tax payment by those in the fourth quintile.

Table 2. Net Effects of Taxes and Transfers to an Average Household, by Income Quintile, 2009

\begin{tabular}{cccccccc}
\hline & \multicolumn{3}{c}{ Benefits } & \multicolumn{3}{c}{ Taxes } & $\begin{array}{c}\text { Net } \\
\text { Gain/loss }\end{array}$ \\
\cline { 2 - 6 } & Cash & In-kind & Total & Direct & Indirect & Total & 10,278 \\
\hline Bottom & 6,883 & 7,555 & 14,438 & $-1,195$ & $-2,965$ & $-4,160$ & 9,866 \\
$2^{\text {nd }}$ & 8,280 & 7,252 & 15,535 & $-2,200$ & $-3,466$ & $-5,666$ & 3,918 \\
$3^{\text {rd }}$ & 6,139 & 7,088 & 13,225 & $-4,850$ & $-4,459$ & $-9,309$ & $-3,678$ \\
$4^{\text {th }}$ & 3,949 & 6,162 & 10,111 & $-8,403$ & $-5,386$ & $-13,789$ & $-19,826$ \\
Top & 1,992 & 5,123 & 7,115 & $-19,500$ & $-7,441$ & $-26,941$ & 111 \\
\hline Average & 5,448 & 6,636 & 12,084 & $-7,230$ & $-4,743$ & $-11,973$ & \\
\hline
\end{tabular}

Data source: Office of National Statistics, 2009; in $£$. 
As shown in Table 3, the tax-transfer system has trimmed the income share going to the top 20 percent from 51 percent to 44 percent, while lifting the income shares of the bottom quintiles from 2.5 percent to 6.8 and 6.9 percent to 11.3 percent respectively. Thus the impacts of redistribution are more pronounced for households in the top and bottom income quintiles - a feature analyzed recently in Blundell (2001), Bhattarai and Whalley (2009) and Mirrlees et al. (2010).

Table 3. Share of Original and Post-Tax Income by Quintile, UK, 2009

\begin{tabular}{cccc}
\hline & Original income share & Post-tax income share & Impact of taxes \& transfers, \% \\
\hline Bottom & 2.5 & 6.8 & 4.3 \\
$2^{\text {nd }}$ & 6.9 & 11.3 & 4.4 \\
$3^{\text {rd }}$ & 15.0 & 15.9 & 0.9 \\
$4^{\text {th }}$ & 24.9 & 22.3 & -2.7 \\
Top & 50.7 & 43.8 & -7.0 \\
\hline
\end{tabular}

Data source: Office of National Statistics, 2009

\section{Models of Growth, Fiscal Policy and Welfare in UK}

Modelling exercises conducted under the Macro Modelling Bureau in the UK until the mid-1990s were based on time series econometric techniques rather than full scale general equilibrium analysis (Church, Mitchel, Sault and Wallis (1997)). As Keynesian economists, they generally argued that by spending more on goods and services and infrastructure, budget deficits were helpful in creating more jobs, reducing the unemployment rate, and raising the growth rate of the economy through various multiplier effects. They faced criticism from neoclassical economists who were more concerned about the adverse consequences of a public deficit on capital accumulation and economic growth. Under the classical Ricardian equivalence proposition, these theorists argued that private saving and the public deficit offset each other.

Assuming dynamic general equilibrium mechanisms implicitly for the transmission mechanism of fiscal and monetary policies, Bean (1998) discussed the effectiveness of fiscal and monetary policies in the previous thirty years using a time series analysis of inflation, unemployment, and current account balance. Wren-Lewis et al. (1998) suggested the novel idea of deconstructing the theoretical part from the econometric estimation, and reconstructing the theory from econometric estimation. Both of these exercises focused on macro models, and did not contain a micro-founded general equilibrium system that uses a multi-sectoral input-output and multi-household structure to study the path of inequality over the history of the entire UK economy.

The stochastic growth model of Holland and Scott (1998) adopted the real business cycle (RBC) framework to study the business cycle facts relating to GDP, investment, work-hours and wages. It introduced shocks to preferences of households, and technologies of firms, but skipped growth and redistribution issues that require explicit specification of heterogeneity of firms and households. In a similar vein, with a dynamic macroeconomic model, Hansen and Prescott (2002) have shown how the Malthusian model with fixed land and variable labor inputs in a production function fitted the English economy well from 1250 to 1800 while the Solow model with constant returns to scale technology matches the empirical facts better for the last two centuries, as capital could be substituted for labor resulting from technological advancements. These two models were designed with a single representative household and firm, to explain growth, but obviously not to show the impacts of fiscal policy on income distribution.

By including public goods in the household utility functions, and public capital in the production function, Bruce and Turnovsky (1999) measure the impact of tax and spending policies on growth and welfare on the basis of analytical solutions of a dynamic macroeconomic growth model. Two of their conclusions state that an increase in the income tax rate reduces the growth rate but raises the private consumption ratio, with no effect in the interest rate, and spending on infrastructure raises the growth rate. However, two of their conclusions are counter-intuitive. The authors also state that the consumption tax does not affect the growth rate, and the increase in government consumption has no effect on growth rate or interest rate.

Such paradoxical conclusions from the analytical solutions of this model must have been due to lack of any labor-leisure choice, inter-temporal allocation of time, and the labor supply function for households, or competition across firms for inputs.

By ignoring the role of heterogeneity of households and firms in welfare analysis, this model neither tackles the issue of redistribution nor captures the impacts of backward and forward linkages among industries. It is not possible to study the evolving composition of production, employment and trade and the distribution of income with this model.

There is recent compelling econometric evidence that changes in the mix of taxes and government expenditures have 
both short-run and long-run effects on economic growth: Gemmell, Kneller, and Sanz (2011) estimate a pooled mean group estimator using data for 17 OECD countries from about 1972 to 2004, and find that a move to non-distortionary taxes (and/or "productive" expenditures) has a relatively rapid and persistent impact on growth. This is entirely consistent with the results of the simulations reported in our paper.

\section{Dynamic CGE Tax Model of UK Economy}

Whalley (1975) constructed the first applied general equilibrium model of the UK economy, calibrating it to a micro-consistent input-output dataset, to simulate the comparative static impacts of tax changes on the economy. Piggott and Whalley (1985) updated this work. The dynamic CGE model presented here builds on forward-looking Ramsey (1928) type dynamics, and is an attempt to put theory, data and policy together. This is made possible by recent innovations in information processing, and the computational procedures required for the dynamic general equilibrium modelling of the UK economy (Rutherford (1995), and Bhattarai (2007)).

The DCGE model underlying the current study is close to Bhattarai and Dixon (2014), but this paper focuses on the growth and redistributive impacts of fiscal policy, rather than on the equilibrium unemployment in the UK considered in that study.

The model in this paper is a numerical counterpart to the abstract theoretical Walrasian concepts for a dynamic economy reported in Hicks (1939). It is an advance over the comparative static general equilibrium analysis pioneered in Whalley (1975) because it incorporates a) inter-temporal preferences of households over consumption and leisure, b) choices of firms of the optimal amount of capital and labor inputs, c) a government with inter-temporal balance in its revenue and spending, and d) a dynamic equilibrium in the country's balance of payments with respect to the rest of the world. Given the constrained inter-temporal optimization by households with standard CES preferences and firms with CES technology and CET functions for tradable commodities, this model is able to capture the wide-ranging income and substitution effects of changes in relative prices due to changes in tax policies and government spending activities. This makes it possible to evaluate the impacts of these policy changes on the process of growth, investment, income redistribution and the evolution of the entire UK economy in the 21st century. The functional forms of the model equations are as given in the next section.

\subsection{Preferences}

The model adopts standard Ramsey-type time-separable constant elasticity of substitution (CES) utility functions to measure the welfare of households in each period.

They engage in intra-period and inter-temporal optimization and substitute consumption and leisure based on relative prices, interest rates, wage rates, tax rates and public spending in equilibrium. Demand resulting from this forms multiple nests of goods and services in the economy. Commodities $\left(C_{i, t}^{h}\right)$ are aggregated to a single composite consumption good $\left(C_{i, t}^{h}\right)$ in the first nest and then that composite good is combined with leisure $\left(l_{t}^{h}\right)$ for utility, $\mathrm{U}\left(C_{t}^{h}, l_{t}^{h}\right)$. Finally utilities are aggregated over time to form life-time utility for each household $U_{o}^{h}$. Thus the problem of household $\mathrm{h}$ can be stated as:

$$
\max U_{0}^{h}=\sum_{t=0}^{\infty}\left(\beta^{h}\right)^{t} U_{t}^{h}\left(C_{t}^{h}, l_{t}^{h}\right) \Rightarrow \sigma_{c}^{h}, \sigma_{l}^{h}, \sigma_{u}^{h}, \delta_{c}^{h}, \delta_{l}^{h}, \sigma_{u}^{h}, \sigma_{u c l}^{h} ; \quad 0<\beta^{h}<1
$$

subject to an inter-temporal budget constraint of the form:

$$
\begin{array}{r}
{\left[\sum_{t=0}^{\infty} P_{i, t}\left(1+t c_{i}^{h}\right) C_{i, t}^{h}+w_{j, t}\left(1-t w_{i}^{h}\right) l_{i, t}^{h}\right]} \\
\leq\left[\sum_{t=0}^{\infty} w_{i, t}^{h}\left(1-t w_{i}^{h}\right) \bar{L}_{i, t}^{h}+r_{j, t}\left(1-t k_{i}\right) K_{i, t}^{h}+T_{t}^{h}\right]
\end{array}
$$

Here tax rates on consumption, wages and capital income $\left(t c_{i}^{h}, t w_{i}^{h}, t k_{i}\right)$ are set by the policy makers who aim for optimality and revenue neutrality in the process of tax reform with transfers $T_{t}^{h}$. The solution requires evaluations of Euler conditions for each household. The demands for ten categories of households for each of ten commodities requires the evaluation of 100 demand functions in each period, or 10,000 equations for a horizon of 100 years. Misch, Gemmell, and Kneller (2013) have explored the question of whether models that maximize growth yield the same optimal tax rates as models that (like ours) maximize "welfare" -which may be difficult to parameterize- both for the 
case where government provides public services, and where it provides public capital. Their model is based on a representative household with an infinite lifetime, and they do not allow for a labor-leisure tradeoff. It turns out that their different assumptions are associated with very similar optimal growth rates, which suggests that our findings are likely to be relatively robust to the choice of the form of the utility function.

\subsection{Production Technology}

Each firm in the model has a unit profit function $\left(\Pi_{i, t}\right)$. This is defined in terms of prices of commodities - the composite of prices of domestic sales $\left(P D_{i, t}\right)$, exports $\left(P E_{i, t}\right)$, and prices of primary inputs $\left(P Y_{i, t}\right)$ and intermediate inputs $P_{i, t}$. Firms maximize profit subject to their technology constraints as:

$$
\operatorname{Max} \Pi_{i, t}=\left(\left(1-\psi_{i}\right) P D_{i, t}^{\frac{\sigma_{y}-1}{\sigma_{y}}}+\psi_{i} P E_{i, t}^{\frac{\sigma_{y}-1}{\sigma_{y}}}\right)^{\frac{1}{\sigma_{y}-1}}-\theta_{i} P Y_{i, t}-\theta_{i}^{d} \sum_{t=0}^{\infty} a_{i, t} P_{i, t}, \quad 0<\theta_{i}, \quad \theta_{i}^{d}<1
$$

subject to the production technology:

$$
Y_{j, t}=\Omega_{i, t}\left[\left(1-\delta_{i}\right) K_{i, t}^{\frac{\sigma_{p}-1}{\sigma_{p}}}+\delta_{i} L_{i, t}^{\frac{\sigma_{p}-1}{\sigma_{p}}}\right]^{\frac{\sigma_{p}}{\sigma_{p}-1}}
$$

Here $\psi_{i}$ and $\theta_{i}$ are share parameters, $\sigma_{y}$ and $\sigma_{p}$ are elasticities of substitution in trade and production, $a_{i, t}$ are the intermediate input coefficients giving the economy wide forward and backward linkages across firms and $\Omega_{i, t}$ is the exogenous total factor productivity. Sector specific capital $\left(K_{i, t}\right)$ accumulation occurs as:

$$
I_{i, t}=K_{i, t}-\left(1-\delta_{i}\right) K_{i, t-1}
$$

The real returns $\left(r_{j, t}\right)$ from investment across sectors are determined by the marginal productivity of capital that adjust until the net-of-business-tax returns are equal to the cost of capital across $\operatorname{sectors}\left(R_{i, t}\right)$. The nominal interest rates set by the central bank should be consistent to these real rates in the long run. The wage rate of each household $\mathrm{h}, w_{t}^{h}$, equals the marginal productivity its own labour.

\subsection{Trade Arrangements}

Economy is open to trade. Domestic firms supply products differentiated from their foreign counterparts. Wholesalers are modeled as following an Armington specification in deciding how much to buy in the domestic markets $\left(D_{i, t}\right)$ and how much to import from abroad $\left(M_{i, t}\right)$ while supplying goods $\left(A_{i, t}\right)$ to the economy (equation 6) taking as given export and import prices, $P E_{i, t}$ and $P M_{i, t}$ in the global market (in equation 7). The choices of consumers between imports and domestic consumption depend on the elasticity of substitution $\left(\sigma_{m}\right)$ between domestic supplies and imported commodities; with share of domestic supplies, $0<\delta_{i}^{d}<1$. Exports $\left(E_{i, t}\right)$ and imports of UK are similarly based on the theory of comparative advantage with differentiated products as in equation (3).

$$
A_{i, t}=\left(\delta_{i}^{d} D_{i, t}^{\frac{\sigma_{m}-1}{\sigma_{m}}}+\left(1-\delta_{i}^{d}\right) M_{i, t}^{\frac{\sigma_{m}-1}{\sigma_{m}}}\right)^{\frac{\sigma_{m}}{\sigma_{m}-1}}
$$

The trade is balanced over time in value terms, so:

$$
\sum_{t=0}^{\infty} P E_{i, t} E_{i, t}=\sum_{t=0}^{\infty} P M_{i, t} M_{i, t}
$$

The UK economy, being one of the most liberal economies in the world, has almost no tax on exports, and has minimal tariffs and non-tariff barriers on imports.

\subsection{Government Sector}

The government receives revenue from direct and indirect taxes and tariffs as in equation (8). These taxes are distortionary and affect the marginal conditions of allocation in consumption, production and trade, causing shifts in the demand and supply functions of commodities. It can adopt either a balanced budget, a deficit budget, a cyclically balanced budget, an inter-temporally balanced budget, or it may simply peg the deficit to a fixed debt/GDP ratio. The structure of taxes depends on the circumstances of the economy, policy debates, and rules based on conventions and international commitments made in treaties or agreements (i.e. EU or G20). 


$$
R_{t}=\sum_{h=1}^{H} \sum_{i=1}^{N} t c_{i}^{h} P_{i, t} C_{i, t}^{h}+\sum_{h=1}^{H} \sum_{i=1}^{N} t w_{i}^{h} w_{j, t}^{h} L S_{i, t}^{h}+\sum_{i=1}^{N} t k_{i} r_{i} K_{i, t} \leq G_{t}=\sum_{i=1}^{N}\left(P_{i, t} g_{i, t}\right)+\sum_{h=1}^{H} T_{t}^{h}
$$

People's preferences for public goods determine the degree of freedom the government is given in choosing the size of the public sector relative to aggregate economic activities.

\subsection{General Equilibrium in a Growing Economy}

Equilibrium in the goods, labor, and capital markets occurs when the demand and supply sides balance each other, as stated in equation (13), but more specifically as follows:

$$
\begin{gathered}
Y_{i, t}=\sum_{h=1} C_{i, t}^{h}+I_{i, t}+E_{i, t}+g_{i, t} \\
\bar{L}_{t}^{h}=\bar{L}_{0}^{h} e^{n^{h}, t}=L S_{t}^{h}+l_{t}^{h} ; ; \quad L S_{t}^{h}=\sum_{h=1}^{H} L S_{i, t}^{h} \\
K_{t}=\sum_{i=1}^{N} K_{i, t}=\sum_{i=1}^{N}\left[\left(1-\delta_{i}\right) K_{i, t-1}+I_{i, t}\right]
\end{gathered}
$$

The left hand sides (LHS) and right hand sides (RHS) of these equations contain first order Euler conditions resulting from the dynamic optimization by consumers and producers with respect to relevant commodities or inputs. In each period the empirical version of the model solved here contains ten Euler equations of household demand for ten commodities, ten first order conditions for each of ten types of labor, and ten types of sector specific-capital. In addition there are export and import demand functions for tradable sectors, and revenue and spending equations for the public sector in each period.

The essence of this model can be summarized in four points. First, the general equilibrium path of the economy, $\{P\}_{t}^{T}$ and $\{Q(P)\}_{t}^{T}$, is a stable and dynamically efficient long run sequence of prices and quantities given by the Marshallian forces of demand and supply balance across all markets in each period and over the entire model horizon (in equation 13, and equations 9 to 11). Second, such dynamically efficient allocations results from the system of relative prices of commodities and services, wage rates and interest rates for each period that guarantee market clearing. Their numerical values entirely depend on the parameters of preferences and technology, showing the behavioral responses of consumers and producers in the economy as shown in equation (12). Third, when a model is properly calibrated to the benchmark micro-consistent data set, relative prices in equilibrium are consistent as a Pareto optimal allocation of resources in the economy as in equation (14). Finally a computable model such as this can provide answers to key policy questions for the benevolent government that can choose policies that generate the most equitable distribution of welfare across households to maximize the social welfare function of the economy as in equations (15).

The relative price system in equilibrium (12) is determined solely in terms of parameters representing preferences of households and technologies of firms and initial endowments of capital and labor. Actually how these substitution and share parameters in consumption and production implicitly determine the relative prices can be stated as:

$$
\{P\}_{t}^{T}=p\left\{\begin{array}{c}
\beta^{h}, \alpha_{c}^{h}, \sigma_{c}^{h}, \sigma_{l}^{h}, \sigma_{u}^{h}, \delta_{c}^{h}, \delta_{l}^{h}, \sigma_{u}^{h}, \sigma_{u c l}^{h} \\
\sigma_{i}^{y}, \psi_{i}, \theta_{i}, \theta_{i}^{d}, a_{i, t} \\
\sigma_{p}, \delta_{i}^{p}, \delta_{i} \\
\delta_{i}^{d}, \delta_{i}^{m}, \sigma_{m} \\
t c_{i}^{h}, t w_{i}^{h}, t k_{i}, T_{t}^{h} \\
g_{i}, \delta_{i}, r_{i} \\
\bar{L}_{i, t}^{h}, K_{i, 0}
\end{array}\right\}_{t}^{T}
$$

The price system thus depends on a) share and elasticity of substitution parameters in preferences of households 
$\left(\alpha_{c}^{h}, \sigma_{c}^{h}, \sigma_{l}^{h}, \sigma_{u}^{h}, \delta_{c}^{h}, \delta_{l}^{h}, \sigma_{u}^{h}, \sigma_{u c l}^{h}\right)$ on the demand side b) elasticity of substitution and input share parameters firms $\left(\sigma_{i}^{y}, \psi_{i}, \theta_{i}, \theta_{i}^{d}, a_{i, t}\right)$ and $\left(\alpha_{p}, \delta_{i}^{p}, \delta_{i}\right)$ on the supply side c) share and substitution elasticity parameters $\left(\delta_{i}^{d}, \delta_{i}^{m}, \sigma_{m}\right)$ for international trade d) tax-transfer policy parameters $\left(t c_{i}^{h}, t w_{i}^{h}, t k_{i}, T_{i}^{h}\right)$ on the policy side, and e) initial factor endowments $\left(\bar{L}_{0}^{h}, K_{i, 0}\right)$, and, rates of growth and depreciation and the cost of capital across sectors, $\left(g_{i}, \delta_{i}, r\right)$ for benchmarking the steady state.

The vector of relative prices includes composite price of domestic supplies $\left(P_{i, t}\right)$, the price of domestic output $\left(P D_{i, t}\right)$, exports $\left(P E_{i, t}\right)$, and imports $\left(P M_{i, t}\right)$, and the wage rate for each type of household $\left(w_{j, t}^{h}\right)$ and the user cost of capital across sectors $\left(R_{i, t}\right)$, the real return by firms $\left(r_{i}\right) ; P:\left\{P_{i, t}, P Y_{i, t}, P D_{i, t}, P E_{i, t}, w_{j, t}^{h}, r_{i}, R_{i, t}, P M_{i, t}\right\}_{t}^{T}$. This price vector is obtained by solving for the zero excess demand across all markets as:

$$
\{Q\}_{t}^{T}: E D_{i, t}=D\{P\}_{t}^{T}-S\{P\}_{t}^{T}=0
$$

Given the sequence of these relative prices, $\{P\}_{t}^{T}$ it is possible to solve for the sequence of equilibrium quantities, $\{Q\}_{t}^{T}$. This quantity vector includes optimal consumption-leisure and labor supply choices of households $\left\{C_{t}^{h}, l_{t}^{h}, C_{i, t}^{h}, L S_{i, t}^{h}\right\}_{t}^{T}$ to maximize the temporal and the life time utility; optimal capital and labor input choices and decisions on domestic sales to maximize profits, exports and imports by firms as $\left\{K_{j, t}, L_{j, t}, I_{i, t}, D_{i, t}, E_{i, t}, M_{i, t}, A_{i, t}\right\}_{t}^{T}$ and a sequence of revenue and spending choices of the government $\left\{R V_{t}, G_{t}\right\}_{t}^{T}$ to maximize the social welfare function $\left\{W_{t}\right\}_{t}^{T}$. Finally:

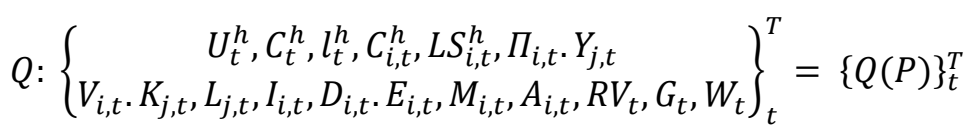

The income redistribution effect in the model occurs not only through the differentiation in the initial endowments of households, but also through variations in tax rates on labor and capital income, as well as affecting the rate of VAT on the consumption of goods and services. Differentiated rates of subsidies and transfers according to various criteria make the income redistribution process more complex.

The optimal design of the tax system, however, requires finding which of these tax instruments are cost effective in raising a given amount of revenue causing the distortions in the optimal choices of households and firms. It is common to apply numerical methods to find the solutions of these models for an empirical policy analysis.

\subsection{Social Welfare Function and Measures of Inequality}

Model solutions were used to compute Gini coefficients for each period in order to measure the impacts of tax policy reform on income distribution. Since the level of lifetime money metric utility is the most relevant indicator of the welfare of house-holds, the focus here is on growth and inequality in it as caused by the changes in the relative prices that are distorted by fiscal policy measures including taxes, transfers and public spending. The level of welfare of every household can rise if the growth rate is higher. This is as a result of more consumption of goods and services.

However it should be taken into account that not every household may benefit in the same proportion; richer households often benefit more from changes than poor households. More equality of income, between a lower growth rate, can reduce the level of the lifetime utility of every household, as they have less for consumption and leisure. This is clearly demonstrated in the solutions of the DCGE model reported below.

Even more difficult questions arise while choosing an appropriate social welfare function, which requires a comparison of levels of utilities of all types of households in the model. The question of how much weight should be given to the sequence of utilities of individual households, $\left\{U\left(C_{1}, l_{1}\right), U\left(C_{2}, l_{2}\right) \ldots U\left(C_{10}, l_{10}\right)\right\}_{t}^{T}$ in the social welfare function is an issue of philosophical controversy. While the maximin criterion of Rawls (1971) requires finding the welfare level of the lowest income household as the basis for an improvement in social welfare, a weak equity axiom of Sen (1974) suggests a policy that generates more equality as measured by lower values of the Gini coefficients. Thus the ranking of alternative policies is possible by computing these coefficients from the model solutions to achieve distributional objectives. In general such social welfare functions are to be determined by the dictates of the policy makers or representatives of people, and implicitly take the functional form as follows:

$$
\left\{W=W\left(U_{1}, U_{2} \ldots U_{10}\right)\right\}_{t}^{T}
$$

It is possible to get the optimal rates of taxes, transfers and spending by constraining the model to revenue neutrality, or social welfare neutrality, to be consistent with the principles set out in Mirrlees (1971), or in Diamond and Mirrlees (1971). When tax rates are properly designed in this manner, these can not only reduce the risks due to income uncertainty for low - as well as high income households, but also ensure that the economy moves along its long run steady state growth path, mitigating the impacts of shocks and distortions as seen in the recent recession. The model results allow one to measure the impacts of changing industrial composition of output, income, investment and 
accumulation of capital on the inequality in utility levels of households, as the amount of commodities that enter into the household utility functions are ultimately determined by these factors.

\section{Data for the Benchmark Economy}

Sectoral share parameters of this dynamic CGE are estimated or calibrated using the 2009 version of the input-output table of the UK economy. Share parameters $\left(\alpha_{c}^{h}, \delta_{i}^{p}, \delta_{i}^{m}, \theta_{i}, \theta_{i}^{d}\right)$ from these input-output and income tables are used to decompose the labour and capital income and consumption across households. Direct and the indirect taxes and transfers $\left(t c_{i}^{h}, t w_{i}^{h}, t k_{i}, T_{t}^{T}\right)$ were constructed from the HMRC and HM-Treasury sources. Sensitivity analysis and literature search were used to assign the values of elasticity parameters $\left(\sigma_{c}^{h}, \sigma_{l}^{h}, \sigma_{u}^{h}, \delta_{c}^{h}, \delta_{l}^{h}, \sigma_{u}^{h}, \sigma_{u c l}^{h}\right)$. Initial endowment of capital and labor for the initial year were constructed from the income share data in the input-output table. Then the labor force, $\bar{L}_{i, t}^{h}$, was subject to exogenous growth, capital stock evolved according to the law of motion of capital as in equation (5). Income and consumption shares were constructed using Table 14 "The effects of taxes and benefits on household income, 2010/11" of Economic Trends from the ONS. This table provides details on the cash and in kind benefits, direct and indirect taxes and the distribution of pre and post-tax income for households in each decile. This framework also provides the data required to evaluate the efficiency implications of unifying the numerous benefits going to low income households as proposed by the Department of Work and Pensions in recent years (http://www.dwp.gov.uk/research-and-statistics/). ${ }^{3}$

Table 4. Benchmark Production Tax Rates, Prices, Income, and Demand by Sector

\begin{tabular}{lrrrrrrrrr}
\hline & $\boldsymbol{w} \boldsymbol{L}$ & $\boldsymbol{r} \boldsymbol{K}$ & $\boldsymbol{C}$ & $\boldsymbol{I}$ & $\boldsymbol{G}$ & $\boldsymbol{X}$ & $\boldsymbol{M}$ & $\boldsymbol{\tau}_{\boldsymbol{k}}$ & $\boldsymbol{\tau}_{\boldsymbol{l}}$ \\
\hline Agri & 3,394 & 7,916 & 15,502 & 815 & 0 & 2,242 & 9,121 & 0.065 & 0.455 \\
Prod & 108,572 & 6,281 & 374,956 & 47,256 & 6,131 & 226,785 & 314,14 & 0.947 & 1.996 \\
Constr & 47,246 & 39,310 & 7,167 & 112,246 & 0 & 1,604 & 1,409 & 0.074 & 0.186 \\
Dist & 161,281 & 63,465 & 131,456 & 802 & 0 & 29,884 & 29,596 & -0.805 & -0.950 \\
Infcom & 47,434 & 28,579 & 38,161 & 24,372 & 3,116 & 20,342 & 12,514 & 0.130 & 0.236 \\
Finins & 56,890 & 67,445 & 45,928 & 118 & 0 & 52,559 & 11,823 & -0.027 & -0.095 \\
Rlest & 6,794 & 84,153 & 139,527 & 4,576 & 0 & 614 & 909 & 0.054 & 2.169 \\
Prfspp & 95,617 & 51,781 & 15,387 & 6,108 & 0 & 54,111 & 33,824 & 0.125 & 0.203 \\
Ghlthed & 220,102 & 32,561 & 65,419 & 1,431 & 313,401 & 3,817 & 2,188 & 0.024 & 0.011 \\
Othrsrv & 29,542 & 11,099 & 51,602 & 313 & 4,701 & 3,630 & 5,737 & -0.006 & -0.007 \\
\hline
\end{tabular}

Data source: ONS 2009. Units (except tax rates): £ million.

Table 5. Benchmark Production, Tax, and Prices, by Sector

\begin{tabular}{lccccc}
\hline & Leisure & Consumption & Income share & Consumption share & \multicolumn{2}{c}{ Income tax rate } \\
Deciles & $\boldsymbol{L}^{\boldsymbol{h}}$ & $\boldsymbol{C}^{\boldsymbol{h}}$ & $\boldsymbol{\theta}^{\boldsymbol{h}}$ & $\boldsymbol{\delta}^{\boldsymbol{h}}$ & $\boldsymbol{t}_{\boldsymbol{i}}^{\boldsymbol{h}}$ \\
\hline H1 & 2,577 & 38,163 & 0.0281 & 0.0627 & 0.0 \\
H2 & 7,451 & 52,401 & 0.0433 & 0.0552 & 0.32 \\
H3 & 14,230 & 66,740 & 0.0551 & 0.0624 & 0.32 \\
H4 & 21,877 & 80,983 & 0.0669 & 0.0850 & 0.32 \\
H5 & 28,269 & 95,550 & 0.0789 & 0.0966 & 0.32 \\
H6 & 35,535 & 109,917 & 0.0908 & 0.1067 & 0.32 \\
H7 & 41,156 & 130,916 & 0.1081 & 0.1078 & 0.32 \\
H8 & 46,294 & 154,484 & 0.1276 & 0.1323 & 0.32 \\
H9 & 54,041 & 178,551 & 0.1521 & 0.1409 & 0.40 \\
H10 & 73,363 & 292,582 & 0.2493 & 0.1945 & 0.45 \\
\hline
\end{tabular}

Data source: ONS 2009. Leisure and consumption in $£$ million.

The above parameters are consistent with equilibrium in the demand and supply sides for each production sector, 
income and expenditure sides of each category of household, and the government sector. The model assumes an intertemporal balance of household and the government budgets within the model horizon, allowing for lending or borrowing, and deficits like the current one, in the short run.

The values assigned to the key parameters of the model are given in Table 4. Further details of the micro consistent data set for 2009, Excel file with model solutions, and GAMS/MPSGE programmes, are available upon request. A counter factual tax scenario consists of implementation of a corporation tax at 20 percent, income tax rates as shown in Table 6 , and a labor income tax of 20 percent.

Table 6. Major Parameters of the DCGE Model of UK

\begin{tabular}{lcccccccccc}
\hline Parameters & $\sigma_{c}^{h}$ & $g_{i, t}$ & $r$ & $\sigma_{u c l}^{h}$ & $\left(\delta_{i, t}\right)$ & $\sigma_{y}$ & $\sigma_{k}$ & $\sigma_{m}$ & $t_{c}^{h}$ & $t w_{i}^{h}$ \\
Assigned values & 1.55 & 0.02 & 0.03 & 0.98 & 0.1 & 2.00 & 1.5 & 3.0 & 0.20 & $0,0.32,0.4,0.45$ \\
\hline
\end{tabular}

$\sigma_{c}^{h}$ and $\sigma_{u c l}^{h}$ : Elasticities of substitution in consumption-leisure and intertemporal choices.

$\sigma_{v}$ : Elasticity of transformation for exports and home sales; $\sigma_{k}$ : capital-labor substitution

$\sigma_{m}:$ Trade (Armington) substitution; $t_{c}^{h}$ : VAT rate; $t w_{i}^{h}:$ income tax rates

$g_{i, t}$ : steady-state growth rate; $\left(\delta_{i, t}\right)$ : rate of depreciation in section $i$.

With ten types of households, eleven production sectors and a horizon of 82 years, numerical methods were adopted to solve the model with the micro-consistent input-output table of the UK constructed by the Office of the National Statistics (ONS) for 2009. The simulations show how various tax and transfer mechanisms recommended in the reports of Meade et al. (1978) and Mirrlees et al. (2010) impact the choices of households and firms in the UK economy.

\section{Results on Redistribution}

The model solutions for the benchmark and counter factual scenarios provide the basis for the evaluation of the current tax and transfer system on both the functional and the size distribution of income for the next century, which then could be compared to the historical accounts presented in section 1. There were mainly two experiments of tax reform considered for this paper. First, the differentiated capital and labor input tax rates in the benchmark given in Table 4, were replaced by uniform tax rates on those inputs. Second, the income tax rate of the richest income category (decile 10) was increased from 45 to 50 percent in the reformed system. While the functional distribution of income between capital and labor is broadly determined by their marginal productivities, as well as the amount of each factor used in production, in line with standard neoclassical principles, the size distribution on the income of the households has historical roots in the socioeconomic structure of the economy as explained in the introductory section above.

Table 7. Redistribution of Utilities Before and After Tax Reforms in the DCGE Model of UK, in ' 000 utils

\begin{tabular}{lcccccc}
\hline & \multicolumn{3}{c}{ Household welfare in 2009 } & \multicolumn{3}{c}{ Household welfare in 2059 } \\
\cline { 2 - 7 } Deciles & Reformed system & Current system & Ratio & Reformed system & Current system & Ratio \\
\hline H1 & 59.1 & 43.1 & 1.368 & 149.2 & 195.0 & 0.765 \\
H2 & 72.0 & 60.1 & 1.198 & 180.4 & 271.5 & 0.664 \\
H3 & 92.5 & 76.6 & 1.208 & 231.8 & 345.9 & 0.674 \\
H4 & 112.8 & 92.9 & 1.214 & 282.8 & 419.7 & 0.676 \\
H5 & 133.7 & 109.7 & 1.219 & 335.0 & 495.2 & 0.664 \\
H6 & 154.2 & 126.8 & 1.222 & 286.4 & 569.6 & 0.678 \\
H7 & 184.2 & 150.2 & 1.226 & 461.6 & 678.4 & 0.680 \\
H8 & 217.9 & 177.3 & 1.229 & 546.1 & 800.6 & 0.682 \\
H9 & 241.1 & 205.8 & 1.172 & 603.0 & 929.1 & 0.649 \\
H10 & 380.2 & 337.2 & 1.128 & 852.5 & $1,522.4$ & 0.626 \\
\hline
\end{tabular}

Note: Constructed from results computed in Excel UK-GE-2013-HH-2070.xls.

As can be seen from Table 7 the DCGE model illustrates that tax changes that enhance wellbeing in the short run are not necessarily growth enhancing and have a limited impact on income distribution. A reformed tax system may generate a favorable pattern of income distribution in the benchmark year of 2009, but such an effect is reduced significantly when the economy evolves over time. Income in 2059 will be about 4.5 five times the current level, with the distribution of income similar to that in 2009. However the proposed reforms are harmful to growth. The model results show that utility levels of households in 2059 would only be about 2.56 times more than that in 2009 on average under such tax reforms. Continuation of the tax-transfer system existing in 2009 thus dominates the various tax reform 
proposals being considered in recent years.

This warrants attention to the long run before any changes are implemented through tax reform. Mirrlees et al. (2010) are right in proposing "a progressive, neutral tax system" that consists of "fairer, less damaging, and simpler taxes than those that we have now". It is clear from the model computations that "Economic welfare could be improved by many billions of pounds if the taxation of income, expenditure, profits, environmental externalities and saving were reformed." The magnitude of the economic impacts from these reforms depend on complicated economy-wide income and substitution effects that characterize the flexibility of markets, as reflected in the elasticities of demand for and supplies of goods and factors of production over time.

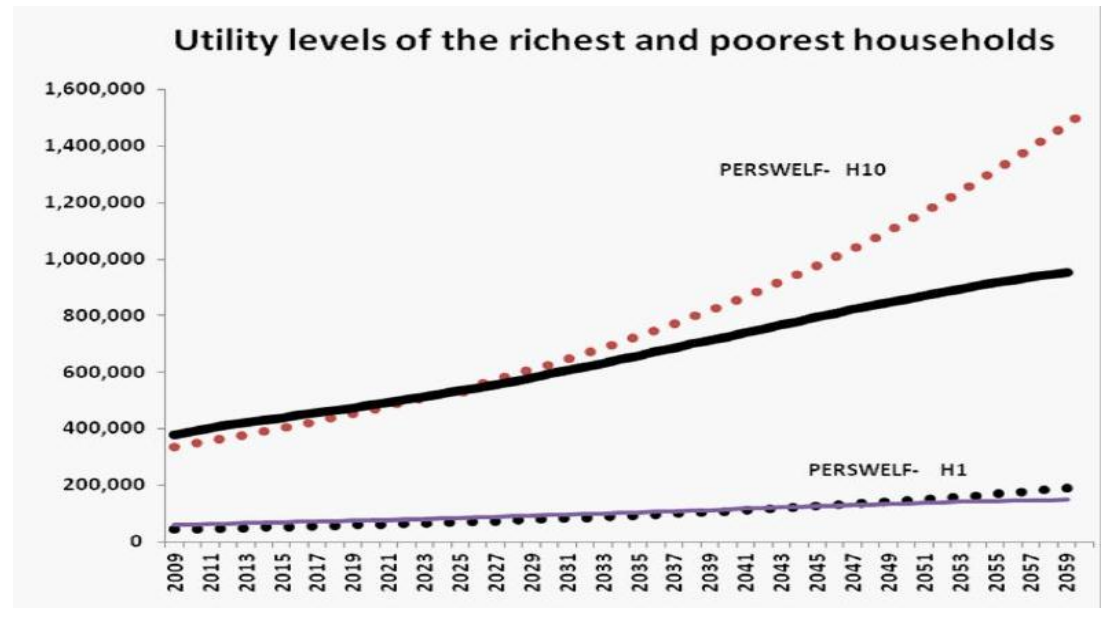

Figure 2. Redistributive Impacts of Policy: DCGE model analysis of money metric utilities

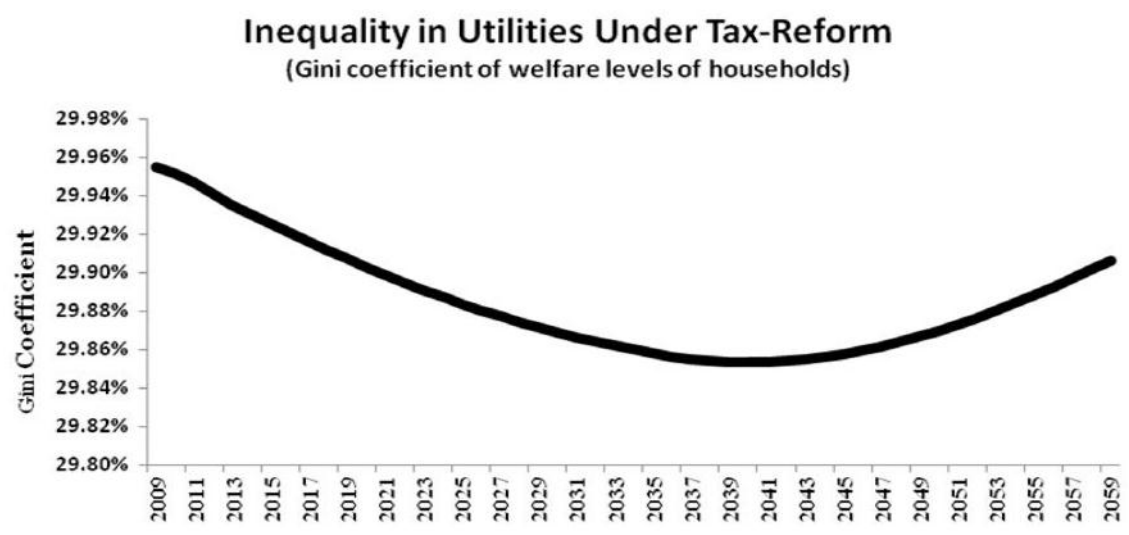

Figure 3. Redistributive Impacts of Fiscal Policy: Gini coefficients

It is post-tax income, or the level of utility from the composite of consumption and leisure, that households care about the most. The paths of inequality for the poorest and the richest households computed from the model solutions are presented in Figure 2. It is clear from the counter factual solutions presented in dotted lines relative to benchmark in solid lines that the contemplated reforms in the system of tax and transfer can lower income inequality but not substantially. Income distribution can become more equal if less distortionary taxes replace more distortionary taxes, as shown by path of average values of utilities in Figure 3. The dotted line of Gini coefficients of life-time utilities in the counter factual scenario are very close relative of the solid line corresponding to the benchmark line in the Lorenz curve in Figure 4. The initial sectoral features of the economy underpinning these results are as given in Figure 5. These representative results of the DCGE model are ultimately determined by inter and intra-temporal preferences of ten categories of households and technological choices available to the producers in all ten production sectors and the design of the tax-transfer system as proposed in recent budget statements. These model solutions could fit to the available theories of distribution that emphasize ability or stochastic factors or individual choice or human capital or inheritance or educational inequality or life cycle decision or public choices for redistribution. 


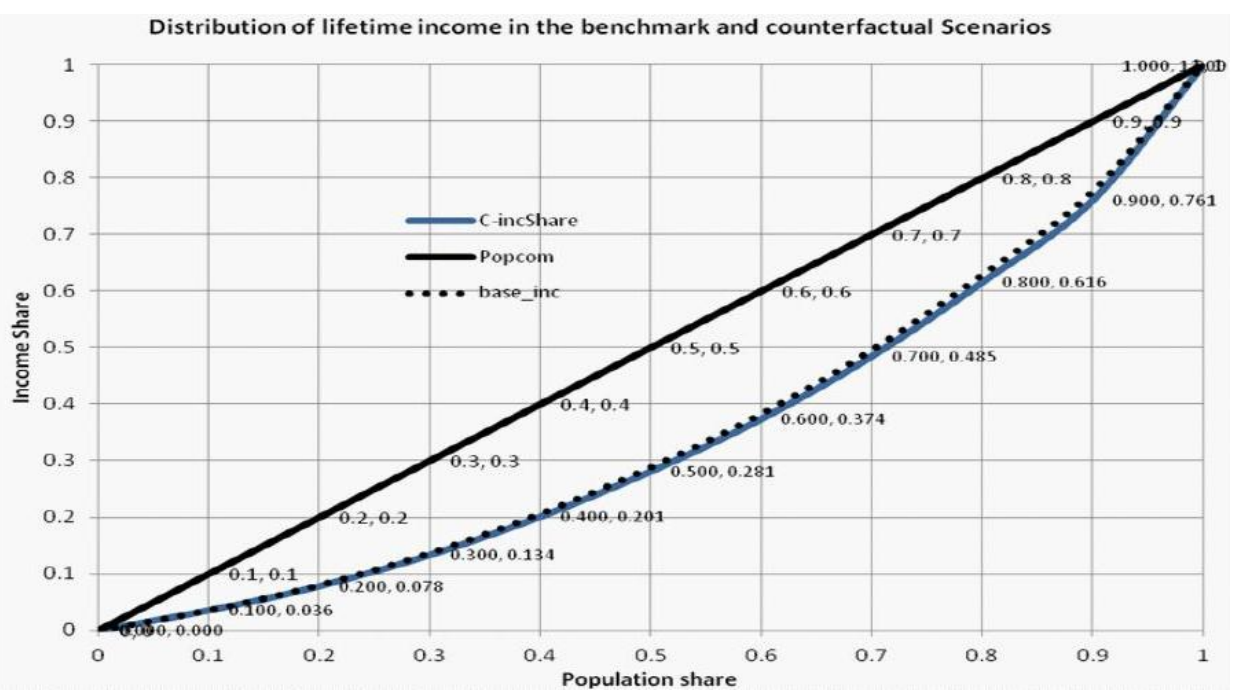

Figure 4. Lorenz Curve for Inequality of Lifetime Utility

These redistribution results are generated from more complex paths of output, employment, investment, consumption, income, revenue, public spending, exports, imports and corresponding relative prices in the model economy. These are only indicative of the evolution of economy and further details on these are available upon request.

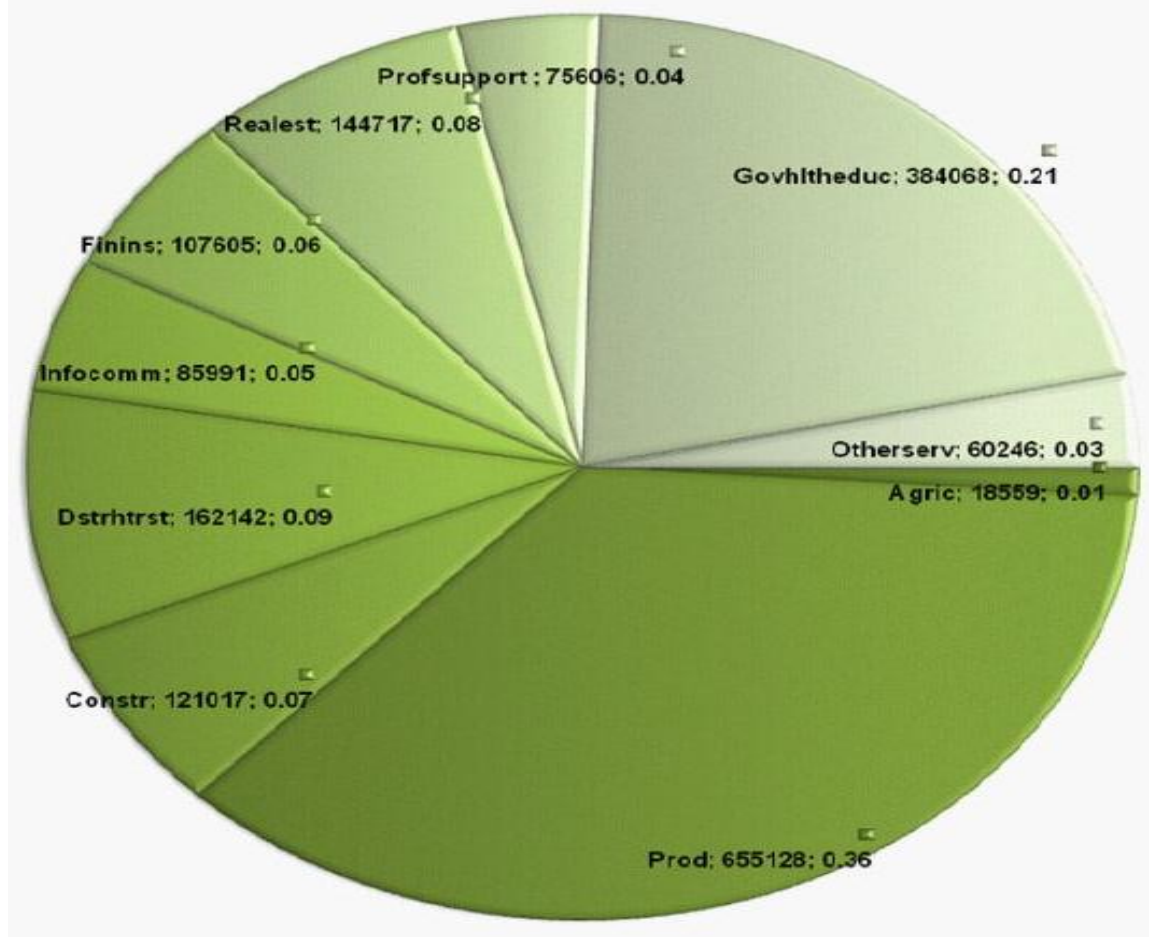

Figure 5. Sectoral Composition of Output in the UK

The programmes and activities that the government can implement to achieve growth and redistribution objectives are limited by its inter-temporal budget constraint. While there are possibilities of designing the tax system to achieve dynamic efficiency in the allocation of resources and in the provision of public goods, including the maximization of positive externalities from investing in public services such as health and education and minimizing negative externalities from punitive taxes. The current balance between direct taxes (the income tax, national insurance, corporate tax and council tax) that bring about 60 percent of total revenue, and the indirect taxes (VAT/Excise and Business rates) for the remaining 40 percent, is not the best composition to minimize the burden of taxes and attain the optimal distribution of income. A careful analysis is required for assessment of how the degree of distortions that those tax instruments, or subsidies on education, health, $R \& D$ or input uses, cause changes in relative prices or in choices of consumers and producers in the economy. It is important to find out the ratios of revenues, spending and deficit to the GDP corresponding to those in Table 1, that are based on the model above. 
While the right (optimal) blending of progressive income and corporation taxes with regressive national insurance contributions, council taxes and VAT, petrol and fuel duties, business and other taxes, is necessary to minimize the burden of taxes, the actual post-tax distribution is also influenced by the allocation of public services among households. Thus it is important to consider the general equilibrium impacts of these revenue and spending sides simultaneously to assess the impacts of fiscal policy on growth and redistribution before policy decisions. Thus the proper quantification of the economic effects of policies on equity, efficiency in allocation, growth and sectoral composition of output and employment over time is a task that can be done only with a more elaborate dynamic general equilibrium model of the UK economy such as the one presented here. Bhattarai, Haughton and Tuerck (2015) present a similar analysis for the US economy.

\section{Conclusions}

Income inequality in the UK was highest during the peak phase of the industrial revolution around 1850 . This is the time when the UK was the economic leader in the global economy, with a sustained growth rate of per capita income of 1.5 percent. Greater concerns about the plight of ordinary workers in the 19th century led to actions by trade unions, politicians and philanthropists that resulted in the enactment of a series of redistributive tax and transfer that changed the focus of public finance to an egalitarian modern welfare state by the middle of the $20^{\text {th }}$ century. U-shaped trends in income inequality from 1950 to 2010, in contrast to the Kuznets curve hypothesis, in both the original and the post-tax income, have caused a lot of discomfort and tension among people and policy makers, particularly when considering the very minimal contribution of recent fiscal policy reforms towards generating economic growth.

An attempt is made here to develop a dynamic multi-sectoral, multi-household general equilibrium (DCGE) model with taxes and transfers and public spending, calibrated to the micro-consistent structural features of household preferences and technological features of firms from the input-output table for year 2009, and public finance accounts of the UK economy. The model results are used to study the equilibrium paths of quantities and prices resulting from the optimal choices of households, firms and the government who play important parts in both the supply and demand sides of the entire UK economy and its evolution in the 21st century. From studying the scenarios of this model, it has been possible to show how tax and transfer policies can be designed to prevent income inequality rising further while ensuring that growth rates of various sectors of the economy are complementary to each other in the steady state. Whether the growth-enhancing and inequality-reducing objectives could be achieved in the long run depends on labor-leisure and consumption-saving choices of low- as well as the high-income households, and on changes in the use of capital or labor inputs by firms in response to the public policies that often aim to achieve a higher rate of growth with greater equality of income and utility for all types of UK households. It is also clear from the model that tax reforms designed to tackle short-run problems may have very detrimental effects on long run growth and may not be helpful in reducing the inequality in the distribution of income over the long term. A sustained rate of economic growth is consistent to an optimal level of inequality. Greater equality in income alone does not guarantee greater welfare for everyone, no matter what the configuration of the social welfare function is. The bottom line is that the average levels of consumption and utility cannot grow when the economy is not growing.

\section{References}

Atkinson, A. B., \& Voitchovsky, S. (2011). The Distribution of Top Earnings in the UK since the Second World War, Economica, 78(311), 440-459. http://dx.doi.org/10.1111/j.1468-0335.2010.00846.x

Bean, C. (1998). The New UK Monetary Arrangements: A View from the Literature, Economic Journal, 108(451), 1795-1809. http://dx.doi.org/10.1111/1468-0297.00375

Bhattarai, K., \& Dixon, H. (2014). Equilibrium Unemployment in a General Equilibrium Model with Taxes, The Manchester School, 82, S1, 90-128. http://dx.doi.org/10.1111/manc.12066

Bhattarai, K., \& Whalley, J. (2009). Redistribution Effects of Transfers, Economica, 76(3), 413-431. http://dx.doi.org/10.1111/j.1468-0335.2008.00686.x

Bhattarai, K. (2007).Welfare Impacts of Equal-Yield Tax Experiment in the UK Economy, Applied Economics, 39(10-12), 1545-1563. http://dx.doi.org/10.1080/00036840600571100

Bhattarai, K., \& Whalley, J. (2000). General Equilibrium Modelling of UK Tax Policy in UK, in Holly S. \& M.Weale (eds.) Econometric Modelling: Technique and Applications, Cambridge University Press.

Bhattarai, K., Haughton, J., \& Tuerck, D. (2015) The Economic Effects of the Fair Tax: Analysis of Results of a Dynamic CGE Model of the US Economy, International Economics and Economic Policy, forthcoming.

Bruce, N., \& Turnovsky, S. J. (1999). Budget Balance, Welfare, and the Growth Rate: Dynamic Scoring of the Long-Run, Journal of Money, Credit and Banking, 31(2), 162-186. http://dx.doi.org/10.2307/2601228

Blundell, R. (2014). Income Dynamics and Life-cycle Inequality: Mechanisms and Controversies, Economic Journal, 
124. http://dx.doi.org/10.1111/ecoj.12133

Blundell, R. (2001). Welfare reform for low income workers, Oxford Economic Papers, 53(2), 189-214.

Church, K.B., Mitchel, P., Sault, J., \& Wallis, K. (1997). Comparative properties of models of the UK economy, National Institute Economic Review, 161, 91-100. http://dx.doi.org/10.1177/002795019716100107

Diamond, P. A., \& Mirrlees, J. A. (1971). Optimal taxation and public production II: Tax Rules, American Economic Review, 61(3-1), 261-278.

Gemmell, N., Kneller, R., \& Sanz, I. (2011). The Timing and Persistence of Fiscal Policy Impacts on Growth: Evidence from OECD Countries, The Economic Journal, 121, F33.F58.

Hansen, G. D., \& Prescott, E. C. (2002). Malthus to Solow, American Economic Review, 92(4), 1205-1217. http://dx.doi.org/10.1257/00028280260344731

Hicks J. R. (1939). Value and Capital: An inquiry into some fundamental principles of economic theory, Oxford: Oxford University Press.

Holland, A., \& Scott, A. (1998). The Determinants of UK Business Cycles Economic Journal, 108(449), 1067-1092. http://dx.doi.org/10.1111/1468-0297.00330

Jenkins, S. P. (1996). Recent trends in UK income distribution, Oxford Review of Economic Policy, 12(1), 29-46. http://dx.doi.org/10.1093/oxrep/12.1.29

Kuznets, S. (1955). Economic Growth and Income Inequality. American Economic Review, 45(1), 1-28.

Meade, J. E., \& R. Stone (1941). The Construction of Tables of National Income, Expenditure, Savings and Investment, Economic Journal, 51(202/203), 216-233. http://dx.doi.org/10.2307/2226254

Meade, J. E., Ironside, J., Bell, F., Kay, K., Macdonald, S., \& Whittington, W. (1978). The Structure and Reform of Direct Taxation. IFS, London: George Allen and Unwin.

Mirrlees, J. A. (1971). An exploration in the theory of optimum income taxation, Review of Economic Studies, 38, 175-208. http://dx.doi.org/10.2307/2296779

Mirrlees J., S., Adam, T., Besley, R., Blundell, S., Bond, R., Chote, M., Gammie, P. J., Myles, G., \& Poterba, J. (2010), Dimensions of tax design: the Mirrlees review, Oxford: Oxford University Press.

Misch, F., Gemmell, N., Kneller, R. (2013). Growth and Welfare Maximization in Models of Public Finance and Endogenous Growth, Journal of Public Economic Theory. 156, 939-967. http://dx.doi.org/10.1111/jpet.12038

Piggott, J., \& Whalley, J. (1985). UK Tax Policy and Applied General Equilibrium Analysis, Cambridge University Press. http://dx.doi.org/10.1017/CBO9780511753008

Ramsey, F. P. (1928). A Mathematical Theory of Saving, Economic Journal, 38, 543-559. http://dx.doi.org/10.2307/2224098

Rawls, J. (1971). Theory of Justice, Cambridge, MA: Harvard University Press.

Rutherford, T. F. (1995). Extension of GAMS for Complementary Problems Arising in applied Economic Analysis, Journal of Economic Dynamics and Control, 19, 1299-1324. http://dx.doi.org/10.1016/0165-1889(94)00831-2

Sen, A (1974). Informational bases of alternative welfare approaches: Aggregation and income distribution, Journal of Public Economics, 3(4), 387-403. http://dx.doi.org/10.1016/0047-2727(74)90006-1

Snowden, P. (1907).The Socialist Budget, London: George Allen.

Stone, R. (1961). Input-output and National Accounts, Paris: OECD.

Whalley, J. (1975). A General Equilibrium Assessment of the 1973 United Kingdom tax reform, Economica, 42(166), 139-161. http://dx.doi.org/10.2307/2553589

Wren-Lewis, S., Darby, J., Ireland, J., \& Ricchi, O. (1996). The Macroeconomic Effects of Fiscal Policy: Linking an Econometric Model with Theory, Economic Journal, 106(436), 543-559. http://dx.doi.org/10.2307/2235562 


\section{A Data Appendix}

Micro-consistent Data for Benchmarking: Input-Output Table of UK: 2009

Table 8. Input-output Transaction Table, 2009

\begin{tabular}{lrrrrrrrrrr}
\hline & Agri & \multicolumn{1}{c}{ Prod } & Constr & Dist & Infcom & Finins & Rlest & Prfspp & Ghlthed & Othrsrv \\
\hline Agri & 3,127 & 12,686 & 250 & 1,622 & 8 & 0 & 0 & 15 & 112 & 20 \\
Prod & 7,256 & 289,576 & 35,007 & 66,800 & 13,040 & 6,002 & 622 & 11,790 & 71,029 & 6,674 \\
Constr & 426 & 4,722 & 57,324 & 13,139 & 1,639 & 4,300 & 9,765 & 2,075 & 6,725 & 784 \\
Dist & 974 & 17,089 & 3,467 & 60,804 & 4,062 & 13,401 & 696 & 9,064 & 14,481 & 1,855 \\
Infcom & 227 & 6,245 & 1,444 & 18,376 & 15,795 & 13,174 & 1,261 & 9,884 & 9,890 & 3,483 \\
Finins & 863 & 14,741 & 4,369 & 11,293 & 2,729 & 20,750 & 44,549 & 5,918 & 6,781 & 1,233 \\
Rlest & 139 & 1,558 & 1,980 & 15,065 & 1,157 & 3,938 & 1,139 & 1,723 & 5,356 & 723 \\
Prfspp & 790 & 25,019 & 16,794 & 43,919 & 19,727 & 26,786 & 4,538 & 76,723 & 33,101 & 12,561 \\
Ghlthed & 32 & 2,502 & 1,511 & 5,298 & 1,107 & 2,560 & 3,370 & 9,068 & 48,167 & 782 \\
Othrsrv & 77 & 938 & 100 & 1,725 & 3,085 & 939 & 51 & 2,201 & 4,869 & 6,628 \\
\hline
\end{tabular}

Data source: ONS 2009. Units: £ million.

Table 9. Consumption of Households by Sectors in UK, 2009

\begin{tabular}{lrrrrrrrrrr}
\hline & Agri & Prod & Constr & \multicolumn{1}{l}{ Dist } & Infcom & Finins & Rlest & Prfspp & Ghlthed & Othrsrv \\
\hline H1 & 435 & 10,520 & 201 & 3,688 & 1,071 & 1,541 & 3,915 & 432 & 1,835 & 1,448 \\
H2 & 671 & 16,224 & 310 & 5,688 & 1,651 & 2,377 & 6,037 & 666 & 2,831 & 2,233 \\
H3 & 854 & 20,663 & 395 & 7,244 & 2,103 & 3,027 & 7,689 & 848 & 3,605 & 2,844 \\
H4 & 1,037 & 25,073 & 479 & 8,790 & 2,552 & 3,673 & 9,330 & 1,029 & 4,375 & 3,451 \\
H5 & 1,223 & 29,583 & 565 & 10,372 & 3,011 & 4,334 & 11,008 & 1,214 & 5,161 & 4,071 \\
H6 & 1,407 & 34,031 & 650 & 11,931 & 3,463 & 4,985 & 12,66 & 1,397 & 5,937 & 4,683 \\
H7 & 1,676 & 40,532 & 775 & 14,210 & 4,125 & 5,938 & 15,083 & 1,663 & 7,072 & 5,578 \\
H8 & 1,977 & 47,829 & 914 & 15,769 & 4,868 & 7,007 & 17,798 & 1,963 & 8,345 & 6,582 \\
H9 & 2,358 & 57,037 & 1,090 & 19,997 & 5,805 & 8,355 & 21,224 & 2,341 & 9,951 & 7,850 \\
H10 & 3,864 & 93,463 & 1,786 & 32,767 & 9,512 & 13,692 & 34,779 & 3,835 & 16,307 & 12,863 \\
\hline
\end{tabular}

Data source: ONS 2009. Units: $£$ million. 
Table 10. Pattern of Income Distribution by Income Deciles in UK in 2009 (in £ ‘000)

\begin{tabular}{|c|c|c|c|c|c|c|c|c|c|c|c|}
\hline & Bottom & $2^{\text {nd }}$ & $3^{\text {rd }}$ & $4^{\text {th }}$ & $5^{\text {th }}$ & $6^{\text {th }}$ & $7^{\text {th }}$ & $8^{\text {th }}$ & $9^{\text {th }}$ & Top & All \\
\hline Household (in mln) & 2.6 & 2.6 & 2.6 & 2.6 & 2.6 & 2.6 & 2.6 & 2.6 & 2.6 & 2.6 & 26.2 \\
\hline Original income & 3.6 & 6.6 & 9.9 & 13.6 & 18.4 & 26.6 & 35.2 & 44.1 & 57.4 & 105.6 & 32.1 \\
\hline Cash benefits & 6.1 & 8.1 & 8.4 & 8.2 & 7.3 & 6.0 & 4.7 & 3.5 & 2.4 & 1.9 & 5.6 \\
\hline Gross income & 9.6 & 14.6 & 18.4 & 21.8 & 25.7 & 32.6 & 39.9 & 47.5 & 59.8 & 107.5 & 37.7 \\
\hline Direct taxes & 1.1 & 1.4 & 2.1 & 2.9 & 3.8 & 5.7 & 7.7 & 10.3 & 13.9 & 25.6 & 7.5 \\
\hline Disposable income & 8.5 & 13.2 & 16.3 & 18.9 & 21.9 & 26.9 & 32.2 & 37.3 & 45.9 & 81.9 & 30.3 \\
\hline Indirect taxes & 3.5 & 3.2 & 3.6 & 3.9 & 4.5 & 5.1 & 5.7 & 6.3 & 7.3 & 9.4 & 5.3 \\
\hline Post-tax income & 5.0 & 10.0 & 12.6 & 15.0 & 17.4 & 21.8 & 26.5 & 31.0 & 39.0 & 72.5 & 25.0 \\
\hline In-kind benefits & 7.4 & 8.1 & 7.7 & 7.5 & 7.2 & 7.7 & 7.3 & 6.4 & 6.0 & 5.6 & 7.1 \\
\hline Final income & 12.4 & 18.1 & 20.3 & 22.5 & 24.6 & 33.7 & 33.7 & 37.3 & 44.6 & 78.1 & 32.1 \\
\hline
\end{tabular}

Source: ONS Table 14: Average incomes, taxes and benefits by decile group of all households, 2010/11.

Table 11. Structure of Public Revenue and Expenditure in UK in 2012/2013 ( $£$ billion)

\begin{tabular}{|c|c|c|c|c|c|}
\hline Sources of revenue & Revenue (£bn) & $\%$ & Expenditure item & Spending (£bn) & $\%$ \\
\hline Income tax & $155(150)$ & $25(27)$ & Social protection & $220(194)$ & $31(28)$ \\
\hline National insurance & $107(99)$ & $17(18)$ & Personal social services & $31(32)$ & $4(4)$ \\
\hline Corporation tax & $39(43)$ & $6(8)$ & Health & $137(122)$ & $19(18)$ \\
\hline Excise tax & $47(46)$ & $8(8)$ & Education & $97(89)$ & $13(13)$ \\
\hline VAT & $103(81)$ & $17(15)$ & Transport & $21(22)$ & $3(3)$ \\
\hline Business tax & $27(25)$ & $4(5)$ & Defence & $40(40)$ & $6(6)$ \\
\hline Council tax & $27(25)$ & $4(5)$ & Industry, Agr, Employment & $19(20)$ & $2(3)$ \\
\hline \multirow[t]{4}{*}{ Other } & 107 (79) & $17(14)$ & Housing \& Environment & $28(27)$ & $3(4)$ \\
\hline & & & Public order and safety & $31(35)$ & $4(4)$ \\
\hline & & & Debt and interest & $51(44)$ & $7(11)$ \\
\hline & & & Other & $53(73)$ & $7(10)$ \\
\hline Total & $612(548)$ & $100(100)$ & Total & $720(696)$ & $100(100)$ \\
\hline
\end{tabular}

Source: OBR and HM Treasury (Gorge Osborne 2013) - Budget statement, March. Figures in parentheses refer to 2011/12. See http://www.hm-treasury.gov.uk/junebudget_diagrams.htm and http://www.hm-treasury.gov.uk/ and http://budgetresponsibility.independent.gov.uk/.

Notes :

${ }^{1}$ Based on time series data available at http://www.ggdc.net/maddison/.

${ }^{2}$ Public finance in the UK, until 1815, was limited to heavy borrowing to finance military and naval expenses during wars, and redeeming such debts using revenues from rents, royalties and indirect taxes in peacetime. Equity issues were ignored in the traditional feudalistic or mercantilist mind-set of .the rich man in his castle, the poor man at his gate, God made them high and lowly and ordered their estate., even after the Magna Carta (1215) and the Glorious Revolution (1688) that transferred political power to the people and the parliament. In the four cannons of taxation of equity, certainty, convenience and economy, Adam Smith (1776) was more concerned for efficiency than for redistribution. Later on, many socialist reformers and radical thinkers including William Wilberforce, Robert Owen and Karl Marx became more concerned with the deteriorating living conditions of workers. They advised unions to organise and agitate for more equal rights, higher wages and better working conditions. They also strongly argued against the iron law of wages that existed then, despite rising trends of labor productivity. The substitution of relatively cheaper capital for labor during the process of industrialisation was a cause of rising productivity.

This movement raised the number of MPs representing workers like Phillip Snowden, who in "The Socialist Budget" booklet of 1907 wrote that "the test of civilisation is in the extent to which the people as a whole enjoy the blessings of national progress"," the existence of a rich class, whose riches are the cause of poverty of masses, is the justification for 
the taxation of the rich" and the "existence of a rich class is a danger to the state".

${ }^{3}$ Sectoral aggregation from 97 sector input-output Table for this model: Agric: Agriculture [1-3]; Prod: Production [5-39]; Constr: Construction [41-43]; Dist: Distribution, transport, hotels and restaurants [45-56]; Infcm: Information and communication [58-63]; Finins: Financial and insurance [64-66]; Rlest: Real estate [68.1-2-68.3]; Prfspp: Professional and support activities [69.1-82]; Ghlthed: Government, health \& education [84-88]; Othrsrv: Other services [90-97].

Acknowledgements: Earlier versions of it were presented to the AEA Annual Conference in Chicago in January 2012, EEA/ESEM Conference in Malaga in August 2012, the Royal Economic Society Conference London in April 2013. We appreciate Professor Peter Hammond of the University of Warwick for valuable comments in the final version of this paper. Correspondence: K. Bhattarai, University of Hull Business School, Hull, HU6 7RX, UK. email: K.R.Bhattarai@hull.ac.uk; Phone: 44-1482463207; Fax: 44-1482463484.

\section{(cc) $\mathrm{Br}$}

This work is licensed under a Creative Commons Attribution 3.0 License. 